\title{
Peran Guru Dalam Peningkatan Kemampuan Berhitung 1-10 Melalui Permainan Fruits Monopoly Pada Anak Usia Dini
}

\author{
Yenny Dwi Astutik ${ }^{a}$, Ridwan $^{\text {a }}$, Hanggara Budi Utomo ${ }^{b}$ \\ aPG-PAUD, FKIP, Universitas Nusantara PGRI Kediri \\ bPG-PAUD, FKIP, Universitas Nusantara PGRI Kediri
}

Corresponding e-mail: yennydwiastutik17@gmail.com, ridwan@unpkediri.ac.id, hanggara@unpkediri.ac.id

Abstrak: Kemampuan berhitung yang merupakan salah satu komponen dari kemampuan dalam bidang kognitif, merupakan hal yang penting untuk dikembangkan dalam diri anak. Mengembangkan kemampuan berhitung anak usia dini dapat dilakukan melalui permainan. Hal ini akan lebih efektif karena dunia anak adalah dunia bermain, di mana permainan Fruits Monopoly adalah salah satunya.. Tujuan dari penelitian ini untuk mengkaji peran guru terhadap peningkatan kemampuan berhitung 1-10 melalui permainan fruits monopoly pada anak usia dini. Pendekatan penelitian yang digunakan adalah studi kasus. Teknik pengumpulan dan penggalian data menggunakan observasi, wawancara, dan studi dokumentasi. Hasil penelitian mengindikasikan bahwa permainan fruits monopoly secara efektif mampu memberikan pengaruh pada kemampuan berhitung 1-10 pada anak usia dini, khususnya anak kelompok bermain. Permainan fruits monopoly menyebabkan proses pembelajaran menjadi lebih menarik, efektif, dan berpusat pada anak didik untuk lebih aktif dalam pembelajaran. Melalui permainan ini, anak belajar untuk berhitung objek nyata yang anak sukai dalam atmosfer yang menyenangkan dan nyaman.

Kata Kunci: kemampuan berhitung 1-10, permainan fruits monopoly, anak usia dini

Abstract: The ability to count which is one component of the ability in the cognitive field is an important thing to develop in children. Developing the ability to count early childhood can be done through games. This will be more effective because the world of children is a world of the play, where the game Fruits Monopoly is one of them. The purpose of this study is to examine the role of teachers in improving the ability to count 1-10 through the game monopoly fruits in early childhood. The research approach used is a case study. Data collection and extracting techniques use observation, interviews, and documentation studies. The results indicate that the game Fruits Monopoly can effectively influence the ability to count 1-10 in early childhood, especially children in playgroups. The game Fruits Monopoly causes the learning process to be more interesting, effective and centered on students to be more active in learning. Through this game, children learn to count real objects that children love in a pleasant and comfortable atmosphere.

Keywords: the ability to count 1-10, the game Fruits Monopoly, early childhood 
Yenny Dwi Astutik, Ridwan, Hanggara Budi Utomo, Peran Guru Dalam Peningkatan Kemampuan Berhitung 1-10 Melalui Permainan Fruits Monopoly Pada Anak Usia Dini

\section{PENDAHULUAN}

Makna anak usia dini menurut NAEYC (National Association for The Education of Young Children) adalah anak yang berada pada rentang usia 0-8 tahun, yang terdiri atas program pendidikan di taman penitipan anak pada keluarga, pendidikan prasekolah, baik swasta ataupun negeri, TK, dan SD (Syaodih, 2005). Pemberlakuan usia anak dini di Indonesia berada pada rentang usia 0-6 tahun. Hal ini sesuai dengan Permendikbud nomor 137 tahun 2014 yang menjelaskan bahwa pendidikan anak usia dini adalah upaya pembinaan yang ditujukan kepada anak sejak lahir sampai usia 6 (enam) tahun yang dilakukan dengan pemberian rancangan pendidikan dengan fungsi membantu pertumbuhan dan perkembangan jasmani dan rohani, sehingga anak memiliki kesiapan dalam memasuki pendidikan lebih lanjut (Kementerian Pendidikan dan Kebudayaan, 2014).

Pendidikan anak usia dini merupakan pendidikan mendasar dan sangat penting dalam pengembangan sumber daya manusia, dimana pada usia dini dapat terbentuk potensi kecerdasan dan dasar-dasar perilaku anak. Masa usia dini disebut sebagai the golden age (usia emas). Hal ini perlu dipahami bahwa anak memiliki potensi untuk menjadi lebih baik di masa mendatang, dengan dukungan, stimuli, bimbingan, bantuan dan perlakuan yang sesuai dengan tingkat pertumbuhan dan perkembangannya dari orang dewasa (Noorlaila, 2010).

Salah satu aspek yang harus dikembangkan oleh anak usia dini adalah aspek perkembangan kognitif. Perkembangan kognitif anak meliputi kemampuan otak anak dalam memperoleh, mengelola, dan mengunakan informasi tersebut menjadi sebuah pengetahuan bagi anak. Kemampuan kognitif sebagaimana sesuai dengan Permendikbud No. 137 tahun 2014, terdiri atas beberapa aspek, diantaranya: kemampuan belajar dan pemecahan masalah; kemampuan berfikir logis; dan kemampuan berfikir simbolik (Kementerian Pendidikan dan Kebudayaan, 2014).

Berbagai cara untuk menggali kemampuan kognitif yang dimiliki oleh anak dapat dilakukan melalui kegiatan pengembangan kemampuan berhitung. Kemampuan berhitung dapat didefiniskan sebagai kemampuan anak dalam menggunakan penalaran, logika dan angka-angka. Kemampuan berhitung juga terkait dengan kemampuan matematika, seperti halnya kegiatan mengurutkan bilangan atau membilang dan mengenal jumlah. Keberfungsian dari kemampuan berhitung ini adalah untuk mengembangkan pengetahuan dasar matematika, seperti pengenalan konsep bilangan, lambang bilangan, warna, bentuk, ukuran, ruang, posisi dan dapat membentuk sikap logis, kritis, cermat dan kreatif pada diri anak (Muijs \& Renolds, 2008).

Kemampuan berhitung merupakan salah satu bentuk dari kemampuan simbolik yang berarti kemampuan untuk memrepresentasikan obyek dan peristiwa kedalam lambang yang bersifat konkret. Minat anak terhadap angka umumnya sangat besar dikarenakan konsep tentang angka sering dijumpai di lingkungan sekitar anak, artinya, angka menjadi bagian dari kehidupan sehari-hari (Triharso, 2013).

Salah satu permasalahan yang dihadapi pada anak TK Dharma Wanita I Karangsemi adalah kurang berkembangnya kemampuan berhitung anak- anak di kelompok bermain. Anak mengalami kesulitan misalnya ketika diminta berhitung mulai dari angka 1-10, dan biasanya terhenti pada angka "tiga". Ketika melanjutkan dari angka "tiga" anak-anak langsung menyebutkan angka "lima", sehingga angka "empat" terlewati dan anak melanjutkan dengan menghitung angka secara acak. Hal ini terlihat bahwa sebagian besar anak di kelompok bermain belum mampu menghitung dengan baik.

Berdasarkan pengamatan peneliti, terdapat faktor yang menyebabkan rendahnya kemampuan berhitung pada anak-anak di kelompok bermain tersebut, salah satunya adalah guru hanya menggunakan media gambar yang dibuat langsung oleh guru di papan tulis. Media tersebut dirasakan belum efektif untuk meningkatkan kemampuan anak mengenal angka secara optimal. Anak terlihat kurang antusias dan kurang fokus pada kegiatan pembelajaran, dan anak mengalihkan perhatiannya dengan bermain dengan temannya.

Berdasarkan permasalahan tersebut, maka perlu adanya upaya untuk membuat kegiatan kreatif yang bermakna, khususnya untuk mengembangkan kemampuan berhitung pada anak usia dini. Salah satu upaya yang dapat dilakukan adalah melalui kegiatan bermain. Aktivitas bermain bagi anak memiliki peranan yang penting untuk mengembangkan perilaku sebelum anak mulai berteman. Aktivitas bermain menyiapkan anak dalam menghadapi pengalaman sosialnya (Nugraha \& Rachmawati, 2015). 
Bermain pada anak usia prasekolah pada dasarnya, mampu meningkatkan perkembangan secara psikologis, terutama pada kecerdasan anak (Adriana, 2013). Peneliti kemudian mencoba memberikan solusi berdasarkan masalah yang dipaparkan di atas untuk meningkatkan kemampuan berhitung anak melalui permainan kreatif, yaitu fruits monopoly.

Permainan fruits monopoly merupakan permainan adopsi dari permainan The Landlord's Game yang diciptakan oleh Elizabeth Magie (Karwatka, 2016) untuk mempermudah orang mengerti bagaimana tuan-tuan tanah memperkaya dirinya dan mempermiskin para penyewa. Permainan fruits monopoly ini dimodifikasi dengaan menggunakan anak sebagai bidaknya dan menggunakan media dari banner. Menurut Musfiroh (2008) monopoli adalah salah satu media visual yang efektif untuk menyajikan pesan tertentu pada anak, praktis dan ekonomis, dan dapat dibuat sendiri sesuai dengan tema yang ada. Selain menarik perhatian anak, penggunaan media monopoli dapat membuat sajian lebih efisien.

Tujuan dari penelitian ini adalah untuk mengeksplorasi dan mendeskripsikan peran guru terhadap peningkatan kemampuan berhitung 110 melalui permainan fruits monopoly pad anak usia dini di TK Dharma Wanita I Karangsemi.

\section{METODE}

Bentuk penelitian yang digunakan adalah penelitian kualitatif. Tujuan penelitian kualitatif adalah untuk mengeksplorasi dan memahami makna yang oleh sejumlah individu atau sekelompok orang berasal dari masalah sosial (Creswell, 2009). Pendekatan penelitian yang digunakan adalah studi kasus dengan mengkaji dan melihat secara mendalam, utuh dan komprehensif suatu persoalan individu atau kelompok, sehingga akan diungkap secara detail atau mendalam tentang suatu kondisi yang sedang diteliti.

Proses pengumpulan dan penggalian data dalam penelitian ini, peneliti menggunakan beberapa metode yang saling melengkapi yaitu observasi terhadap anak usia 5-6 tahun, wawancara kepada 1 orang kepala sekolah dan 1 orang guru, dan menggunakan studi dokumentasi, seperti RPPH, RPPM, catatan harian, dan penilaian anak yang didokumentasikan oleh guru kelas. Subjek penelitian ini berjumlah 2 orang, yaitu kepala sekolah dan guru kelompok bermain TK Dharma Wanita I Karangsemi

\section{HASIL DAN PEMBAHASAN}

Selama ini, peran guru TK Dharma Wanita I Karangsemi, dalam menstimuli kemampuan berhitung pada anak hanya hanya menggunakan media gambar yang dibuat langsung oleh guru di papan tulis, dan belum mengaplikasikan pengalaman langsung kepada anak dalam berhitung. Seiring dengan berjalannya waktu, guru TK Dharma Wanita I Karangsemi khususnya yang mengajar pada anak kelompok bermain, mulai berbenah dan memunculkan ide untuk meningkatkan kemampuan berhitung anak dengan mengenalkan permainan kreatif hasil adopsi dari permainan The Landlord's Game yang diciptakan oleh Elizabeth Magie (Karwatka, 2016). Permainan tersebut diberi nama permainan fruits monopoly.

Mekanisme Permainan Fruits Monopoly

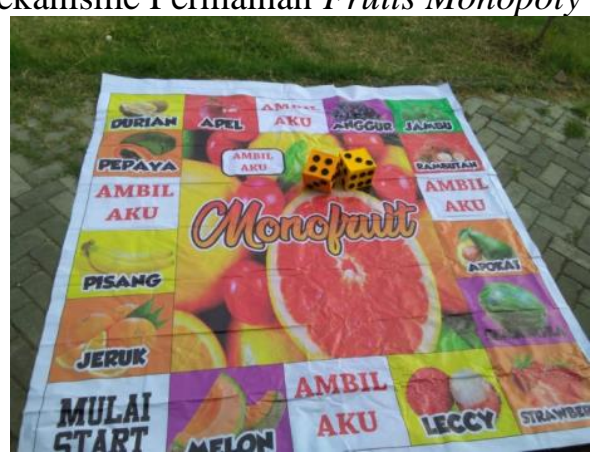

Gambar 3.1 Fruits Monopoly

1. Bahan-bahan :
a. Papan Kayu Ukuran $20 \mathrm{~cm} \times 20 \mathrm{~cm}$
b. Cat Kayu
c. Banner
d. Kertas HVS

2. Alat yang dibutuhkan :
a. Kuas
b. Penggaris
c. Gergaji

3. Cara Membuat :

a. Potong kayu dengan ukuran sisi $20 \mathrm{~cm} \times 20 \mathrm{~cm}$.

b. Menyediakan dua buah dadu dari kardus bekas, 2 buah dadu yang sudah di cat, kemudian diberi titik 1-6.

c. Anak sebagai pengganti bidak dalam permainan monopoly.

d. Banner sebagai kartu petunjuk $200 \mathrm{~cm}$ x $200 \mathrm{~cm}$.

Aturan permainan Fruits Monopoly adalah (a) anak didik berperan sebagai pemain, dilarang membuka dan membaca materi pembelajaran yang terkait dengan tema yang sudah ditetapkan 
selama permainan berlangsung, kecuali ada petunjuk dari permainan fruits monopoly (misalnya kertas yang berisi suatu perintah yang menyuruh pemain untuk menjawab atau melaksanakan perintah yang diberikan oleh guru); (b) permainan dimulai dengan melempar dua dadu bersama-sama, bergantian setiap anak; (c) guru memperhatikan dan mencatat serta memantau jalannya permainan, mulai dari penentuan urutan anak sampai pada selesai permainan; (d) anak yang memiliki angka terbesar pada lemparan dadu akan mendapat urutan awal untuk memulai berjalan pada papan fruits monopoly, begitu seterusnya berjalan berurutan sampai angka terkecil; (e) anak kemudian melempar dua dadu bersamaan, angka yang muncul pada masing-masing dadu kemudian di jumlahkan; (f) Sesuai dengan angka yang muncul pada dadu, maka anak harus berjalan di atas bidak-bidak kelas papan fruits monopoly; (g) ketika anak sampai di kelas "AMBIL AKU", maka anak wajib mengambil kertas yang sudah disediakan, kemudian mengikuti petunjuk yang tertera pada kertas tersebut; (h) pemenang dari permainan dengan menggunakan media fruits monopoly ini ditentukan dari berjalannya anak dalam 1 kali putaran bermain.

Kegiatan permainan fruits monopoly yang sudah dikonsepkan diatas, secara bertahap sudah dilaksanakan. Guru merasakan bahwa permainan fruits monopoly penuh dengan tantangan, menarik, dan menyenangkan. Anak didik pun juga dapat ikut berpartisipasi dan semangat dalam kegiatan pembelajaran ini. Hal ini selaras dengan hasil penelitian oleh Agustiya, Ali, dan Sri (2017); Subroto, Bekti, dan Djoko (2016); menyatakan bahwa pembelajaran dengan menggunakan media permainan monopoli dapat membuat proses pembelajaran siswa menjadi lebih menyenangkan dan efektif. Siswa lebih aktif dalam proses belajar, sehingga proses pembelajaran berpusat pada siswa. Senada dengan hal tersebut, hasil penelitian Ulfa dan Rozalina (2019) menyatakan bahwa media pembelajaran Monopoly Games Smart (MGS) mempengaruhi pemahaman konsep siswa.

Permainan monopoli dapat dimodifikasi sesuai dengan kebutuhan pembelajaran sehingga dapat menjadi pembelajaran yang tepat dan menyenangkan untuk meningkatkan minat belajar peserta didik (Suitriani, 2016). Penggunaan media permainan monopoli dapat mengakibatkan peserta diri merasa tertarik, perhatian, berpartisipasi serta memiliki rasa keinginan dalam mengikuti proses pembelajaran sehingga hal tersebut membangkitkan minat belajar peserta didik menjadi lebih baik dan lebih termotivasi dalam mengikuti proses pembelajaran (Siskawati, Pargito, \& Pujiati, 2016).

Penerapan media monopoli juga dapat membuat peserta dirik belajar langsung dan mengalami sendiri proses pembelajaran. Apabila proses pembelajaran tersebut dilalukan sendiri, maka proses pembelajaran menjadi lebih bermakna, dan proses pembelajaran berpusat pada peserta didik (Siskawati, Pargito, \& Pujiati, 2016).

Selanjutnya, guru dalam kelompok bermain ini juga memperhatikan karakteristik bermain anak didiknya. Ketika guru mengamati memang anak terlihat bermain. Namun seorang guru, perlu mengenali karakteristik anak ketika bermain. Smith, Garvey, Fein dan Vandenberg sebagaimana dikutip Tedjasaputra (2001), penting bagi guru mengenali motivasi dari dalam diri anak untuk bermain; mengenali emosi positif yang dirasakan anak, seperti: senang, antusias, bahagia; anak mudah beralih dari satu aktivitas ke aktivitas lain. Guru lebih menekankan proses daripada hasil akhir, dan perlu memahami bahwa anak tidak merasakan tekanan ketika bermain. Ketika anak merasakan senang dalam bermain, maka anak dapat belajar dengan nyaman, khususnya belajar berhitung angka 1-10 menggunakan media fruits monopoly.

Senada dengan pernyataan di atas, hasil penelitian Khan dan Yuliani (2016) menjelaskan adanya peningkatan yang berarti dalam kemampuan berhitung anak. Rata-rata kemampuan anak dalam membilang, penjumlahan, dan pengurangan angka meningkat hingga siklus terakhir melalui permainan. Anak dapat belajar menghitung benda-benda yang nyata yang ia sukai. Hal ini juga mendukung penjelasan Depdiknas (2007) bahwa permainan berhitung akan lebih berhasil jika anak diberi kesempatan untuk berpartisipasi dan dirangsang untuk menyelesaikan masalahnya sendiri dalam suasana yang aman dan menyenangkan bagi anak melaui permainan.

Dengan demikian, permainan fruits monopoly dapat menjadi sebuah kegiatan yang menarik dan menyenangkan bagi anak, dan selanjutnya dapat memberikan kontribusi bagi guru untuk meningkatkan kemampuan berhitung anak usia dini di kelompok bermain. Tentunya, diperlukan peran guru untuk selalu kreatif dalam mengelola pembelajaran yang bermakna.

\section{KESIMPULAN}

Berdasarkan paparan yang sudah dijelaskan, dapat disimpulkan bahwa permainan 
fruits monopoly secara efektif mampu memberikan pengaruh pada kemampuan berhitung 1-10 pada anak usia dini, khususnya anak kelompok bermain. Permainan fruits monopoly menyebabkan proses pembelajaran menjadi lebih menarik, efektif, dan berpusat pada anak didik untuk lebih aktif dalam pembelajaran. Melalui permainan, anak belajar untuk berhitung secara nyata yang anak sukai dalam suasana kelas yang menyenangkan dan nyaman (Khan \& Yuliani, 2016).

Adapun saran yang diberikan bagi pendidik yang lain bahwa permainan fruits monopoly dapat digunakan sebagai pertimbangan salah satu jenis permainan kreatif untuk meningkatkan kemampuan berhitung anak. Bagi peneliti selanjutnya, supaya memperluas dan mengkaji indikator-indikator kemampuan berhitung anak dengan menggunakan penelitian kuantitatif, atau dengan menggunakan penelitian tindakan kelas. Selain itu, dapat menggunakan permainan fruits monopoly pada kegiatan bidang pengembangan selain bidang kognitif dengan responden yang berbeda.

\section{DAFTAR PUSTAKA}

Adriana, D. (2013). Tumbuh kembang \& terapi bermain pada anak. Jakarta: Salemba Medika.

Agustiya, F., Ali, S., dan Sri, H. (2017). Influence of CTL model by using monopoly game media to the student's motivation and science learning outcomes. Journal of Primary Education. 6(2). 114-119. doi: 10.15294/JPE.V6I2.17559

Creswell, J. W. (2010). Research design: Pendekatan kualitatif, kuantitatif, dan mixed, edisi ketiga. (Terjemahan Achmad Fawaid). Yogyakarta: Pustaka Pelajar.

Depdiknas. (2007). Pedoman pembelajaran permainan berhitung permulaan di taman kanak-kanak. Jakarta: Dirjen Dikdasmen

Kementerian Pendidikan dan Kebudayaan. (2014). Peraturan Menteri Pendidikan dan Kebudayaan Republik Indonesia Nomor 137 Tahun 2014 tentang Standar Nasional Pendidikan Anak Usia Dini. Jakarta: Kementerian Pendidikan dan Kebudayaan Republik Indonesia.

Khan, R.I., \& Yuliani, N. (2016). Meningkatkan kemampuan berhitung anak usia dini melalui permainan bowling kaleng. Universum, 10(1), 65-71.
Muijs, D., \& Reynolds, D. (2008). Efective teaching. Teori dan aplikasi. Yogyakarta: Pustaka Belajar.

Musfiroh, T. (2008). Cerdas melalui bermain. Jakarta: Grassindo

Nugraha, A., \& Rachmawati, Y. (2015). Metode pengembangan sosial emosional (Cet $7 \mathrm{Ed}$ 1). Tangerang Selatan: Universitas Terbuka.

Noorlaila, I. (2010). Panduan lengkap mengajar paud. kreatif mendidik dan bermain bersama anak. Yogyakarta: Pinus Book Publisher.

Siskawati, M., Pargito, dan Pujiati (2016). Pengembangan media pembelajaran monopoli untuk meningkatkan minat belajar geografi siswa. Jurnal Studi Sosial. 4(1), 7280.

Subroto, A.G., Bekti, K., dan Djoko, L. (2016). Pemanfaatan media monopoli untuk meningkatkan keaktifan dan hasil belajar IPA Siswa Kelas III SDN Sugihwaras Kecamatan Maospati Kabupaten Magetan Tahun Pelajaran 2015/2016. Jurnal Florea. 3(2), 49-54.

Suitriani, W. (2016). Penerapan model pembelajaran make a match dan media monopoly games smart (mgs) pada materi sistem ekskresi manusia di MAN Meulaboh1 Aceh Barat. (Skripsi). Universitas Islam negeri Ar-Raniry Darussalam, Banda Aceh.

Syaodih, E. (2005). Bimbingan di taman kanakkanak. Jakarta: Depdiknas.

Tedjasaputra, M.S. (2001). Bermain, mainan dan permainan. Jakarta: PT. Grasindo.

Thiharso, A. (2013). Permainan kreatif dan edukatif untuk anak usia dini. Yogyakarta: Andi Omset.

Ulfa, K., \& Rozalina, L. (2019). Pengembangan media pembelajaran monopoli pada materi sistem pencernaan di SMP. Bioilmi: Jurnal Pendidikan, 5(1), 10-22. doi: 10.19109/bioilmi.v5i1.3753. 